\title{
Hazel improves soil quality of sloping oak stands in a German low mountain range
}

\author{
Dirk MOHR*, Werner ToPP \\ Universität zu Köln, Zoologisches Institut, Terrestrische Ökologie, Weyertal 119, 50923 Köln, Germany
}

(Received 29 October 2003; accepted 14 May 2004)

\begin{abstract}
We compared Quercus petraea monocultures with adjacent mixed oak-hazel (Corylus avellana) stands at gentle (14 ${ }^{\circ}$ ) and steep $\left(25^{\circ}\right)$ slopes of the Ahr-Eifel. The influence of hazel on forest floor mass, soil nutrients, microbial properties and on the abundance of Lumbricidae was studied. Litter mass was greater in mixed stands than in oak monocultures, resulting in a thicker Ah-horizon. Additionally, the $\mathrm{PO}_{4}{ }^{3-}, \mathrm{Ca}^{2+}$ - and $\mathrm{Mg}^{2+}$-contents were higher and the $\mathrm{Al}^{3+}$-content lower in the upper soil of mixed stands. In contrast, the contents of organic carbon, total nitrogen and the $\mathrm{C} / \mathrm{N}$ ratio did not differ between the two soils. Basal respiration, specific microbial activity $\left(q \mathrm{CO}_{2}\right)$ and carbon mineralisation $\left(\mathrm{C}_{\mathrm{min}}\right)$ were higher in mixed stands than in oak monocultures. Lumbricidae showed low densities in three of the stands studied (15-21 ind. $\left./ \mathrm{m}^{2}\right)$ and were almost absent at the oak monoculture on the steep terrain $\left(2 \mathrm{ind} . / \mathrm{m}^{2}\right)$.
\end{abstract}

oak / hazel / decomposition / soil nutrients / Lumbricidae

Résumé - Le noisetier améliore la qualité du sol des peuplements de chênes de basse montagne en Allemagne. Nous avons comparé des monocultures de type Quercus petraea avec des cultures adjacentes mixtes composées de chênes et de noisetiers (Corylus avellana) situées sur des pentes $\left(14^{\circ} / 25^{\circ}\right)$ différentes. L'influence du noisetier sur la masse de litière, les substances nutritives du sol, les propriétés microbiennes et l'abondance de Lumbricidae at été étudiée. Cette étude a montré que la masse de litière est plus élevée dans les cultures mixtes que dans les monocultures de chênes ; il en résulte un épaississement de l'horizon $\mathrm{Ah}$. En outre, les teneurs en $\mathrm{PO}_{4}{ }^{3-}-\mathrm{P}, \mathrm{Ca}^{2+}-$ et $\mathrm{Mg}^{2+}-$ sont plus élevées et les teneurs en $\mathrm{Al}^{3+}$-plus faibles dans les couches supérieures des sols de cultures mixtes. Par contre, la teneur en carbone organique, en azote total ainsi que la relation $\mathrm{C} / \mathrm{N}$ ne diffèrent pas. La respiration de base, l'activité microbienne spécifique $\left(q \mathrm{CO}_{2}\right)$ et la minéralisation carbonique $\left(\mathrm{C}_{\mathrm{min}}\right)$ sont plus élevées dans les cultures mixtes que dans les monocultures de chênes. Les Lumbricidae présentent des densités faibles dans trois des cultures étudiées (15-21 ind./ $\left.\mathrm{m}^{2}\right)$, tandis qu'ils sont pratiquement absents dans les monocultures de chênes en terrain escarpé (2 ind./m²).

chêne / noisetier / décomposition / substances nutritives du sol / Lumbricidae

\section{INTRODUCTION}

Many oak stands (Quercus petraea) in the central European low mountain range were formerly used as simple coppice forests. Nowadays many stands are not commercially used and grow in association with other trees or shrubs. In the Ahr-Eifel hazel (Corylus avellana) is the most common species to form a dense shrub layer below the oak canopy. During the last decades many oak coppice forests were converted into monocultures, and hazel was cut down to enhance the growth of the target trees and to improve accessibility to the forests, especially for hunting.

However, we assume that hazel may improve the ecological sustainability in oak forests. Oak trees may even benefit from the presence of shrubs. The better palatability of hazel litter compared to oak litter [33] could promote decomposition processes by the soil biota and thus enhance nutrient accumulation in soils. Moreover, hazel leaves exhibit higher concentrations of base cations than oak leaves [16] and could therefore improve the buffering capacity of acidified soils as shown for other alkaline plant material [24, 31,32]. Litter as a fuel for the nutrient cycles in upper soil horizons is particularly important in the nutrition of woodlands growing on soils of low nutrient status [10].

To find out if hazel influences soil quality in sloping oak stands we determined several soil physical, chemical and microbial properties and the abundance of Lumbricidae in mixed oak-hazel stands and adjacent oak monocultures.

\footnotetext{
* Corresponding author: D.Mohr@uni-koeln.de
} 


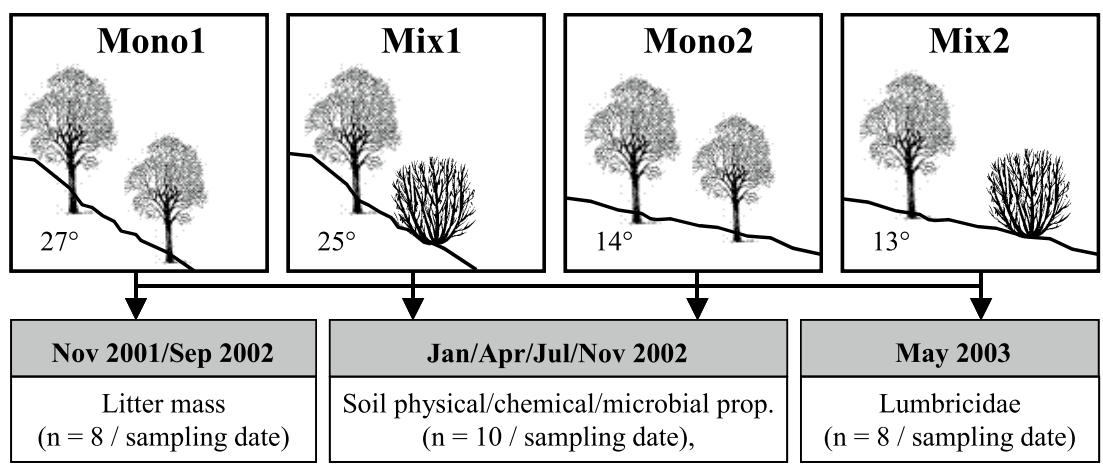

Figure 1. Illustration of the experimental design: Mono1 $=$ oak monoculture, $27^{\circ} ;$ Mix $1=$ oak-hazel; $25^{\circ}$, Mono $2=$ oak monoculture, $13^{\circ}$; Mix2 = oak-hazel, $14^{\circ}$.

\section{MATERIALS AND METHODS}

\subsection{Study area}

The study was conducted in the Ahr-Eifel, Forestry District Adenau, in Rhineland-Palatinate. The Ahr-Eifel is an eastern part of the Eifel-mountains in the Central European low mountain range and is characterized by steep forested hills with elevations up to $700 \mathrm{~m}$ above sea level. The typical tree species at the dry windward hillsides (SW) is sessile oak (Quercus petraea) associated with hazel (Corylus avellana), hornbeam (Carpinus betulus), birch (Betula pendula) or, at very dry and nutrient poor sites, pine (Pinus sylvestris). The humid leeward hillslopes are dominated by oak and beech (Fagus sylvatica). The main bedrock is Devonic slate. The dominant wind direction is from the west/southwest, mean annual rainfall ranges from 675 to $800 \mathrm{~mm}$ and mean annual temperature from 6 to $8{ }^{\circ} \mathrm{C}$. The latter two factors both depend on elevation and exposure. The abundant soil types vary depending on inclination, exposure and plant composition. Lithic Leptosol (Ranker) with shallow $(<5 \mathrm{~cm})$ Ah-horizons predominates at steep and windward oak forests. At leeward sites with mixed cultures an Umbric Cambisol (acid brown earth) with Ah-horizons up to $10 \mathrm{~cm}$ is developed. The thickness of the B-horizon in such soils is highly variable and depends on the soil forming bedrock. Locally, loess layers of varying thickness cover the devonic basis. An important characteristic of the investigation area is the high game density. The population density of red deer was calculated to be 20 individuals per 100 ha. Densities of moufflons and wild boar are also high but there are no reliable calculations yet. Game produces extensive soil disturbances through grazing, trampling and rooting. Over large areas the herb layer is completely removed, soil layers mixed and organic soil horizons eroded.

\subsection{Study sites}

We selected two sites at which oak monocultures (Quercus petraea) were growing next to mixed stands of oak and hazel (Corylus avellana). The sites were $300 \mathrm{~m}$ apart and only differed in the slope gradient $\left(13-14^{\circ}\right.$ vs. $25-27^{\circ}$, respectively). We used the following abbreviations for the investigated locations: Monol $\left(=\right.$ monoculture, $\left.27^{\circ}\right)$, Mix1 (= mixed stand, 25 $)$, Mono2 $\left(=13^{\circ}\right)$ and Mix2 $\left(=14^{\circ}\right)$ (Fig. 1).

Bedrock type (Devonic slate), elevation ( $450 \mathrm{~m}$ ) and exposure $(\mathrm{W})$ were the same at all locations. The litter type at the observed forests is a moder. However, at steep and windward sites litter is often completely removed from the soil due to wind drift and downhill transport. The soil at the locations Mix1, Mono2 and Mix2 is an Umbric Cambisol. At the location Mono1 a Lithic Leptosol is formed. Thickness of the Ah-horizon is $2-10 \mathrm{~cm}$ and thickness of the B-horizon exceeds
$20 \mathrm{~cm}$ (Tab. I). The study sites have remained unmanaged for at least 80 years. The present species composition is the result of land use dating back to the beginning of the nineteenth century. At that time coppice management was practised throughout the region. Oak is the dominant tree species at all sites. The height of the oak trees ranged from 10 to $20 \mathrm{~m}$, crown closure of trees varied between 0.5 and 0.6 at the mixed stands and between $0.7-0.9$ at the monocultures. Crown closure of hazel at the mixed stands ranged from 0.4 to 0.6 . The herb layer covered 1.4 to $8.8 \%$ of the soil area of the investigated forest stands.

\subsection{Soil chemical analyses}

Soil samples $(n=10)$ were taken at random from the Ah-horizon in January, April, July and November of 2002 to reach a total number of 40 replicates per location and year. Soil samples were sieved at a mesh size of $2 \mathrm{~mm}$. Soil $\mathrm{pH}$ was determined according to Schlichting and Blume [41] with a microprocessor $\mathrm{pH}-$ meter ( $\mathrm{pH} 320$, WTW) after extraction with $1 \mathrm{M} \mathrm{KCl}$. All other chemical analyses were conducted with air-dried soil. Content of organic carbon $\left(\mathrm{C}_{\text {org }}\right)$ was calculated from $\mathrm{CO}_{2}$ measurements (Total Organic Carbon Analyser, Ströhlein Instruments) after combustion at $550{ }^{\circ} \mathrm{C}$. Total nitrogen $\left(\mathrm{N}_{\mathrm{t}}\right)$ content was analysed using the Kjeldahl method. The analysis of extractable phosphate-ions in the soil was performed colorimetrically with the Vanadate-method as described in Steubing and Fangmeyer [43]. Plant available contents of calcium $\left(\mathrm{Ca}^{2+}\right)$, magnesium $\left(\mathrm{Mg}^{2+}\right)$ and potas$\operatorname{sium}\left(\mathrm{K}^{+}\right)$were extracted from $10 \mathrm{~g}$ soil with $50 \mathrm{~mL} 1 \mathrm{MNH}_{4} \mathrm{NO}_{3}$ solution $[17,49]$ by homogenisation (horizontal shaker for $2 \mathrm{~h}$ ) and filtration. The ion contents in the suspension were analysed with an Atomic Absorbance Spectrophotometer (AAS, PERKIN-ELMER GmbH). $\mathrm{Al}^{3+}$-analysis was performed reflectometrically with MERCK teststrips after extraction with $2 \mathrm{M} \mathrm{KCl}$.

\subsection{Soil microbial analyses}

Soil samples were taken as described for the soil chemical analyses. The maximum water retention capacity $\left(\mathrm{WRC}_{\max }\right)$ of the sieved soil $(2 \mathrm{~mm})$ and the soil moisture were measured gravimetrically as described in Alef [2]. For microbial analyses the moist soils were, if necessary, adjusted to $40-60 \%$ of the maximum water retention capacity of the sieved soils by adding distilled water and incubated at $20^{\circ} \mathrm{C}$ for two days. Potential microbial activity was determined using the method of Skambracks and Zimmer [42], modified for soil samples. Soil is incubated in $\mathrm{CO}_{2}$-free glass vessels for $24 \mathrm{~h}$ at $25^{\circ} \mathrm{C}$ and the release of microbial $\mathrm{CO}_{2}$ measured with a TOC-analyser (Ströhlein Instruments). Microbial biomass $\left(\mathrm{C}_{\mathrm{mic}}\right)$ was analysed using the fumigation-extraction method as according to Vance et al. [47]. The carbon 
Table I. Selected soil properties of the investigation sites Mono1, Mix1, Mono2 and Mix2 (Mono = oak monoculture; Mix = oak-hazel; $1=$ $\left.25-27^{\circ}, 2=13-14^{\circ}\right)$. For soil physical, chemical and microbial properties the median and median absolute deviation of all sampling dates $(n=$ $8-40)$ are presented.

\begin{tabular}{|c|c|c|c|c|c|}
\hline Site & $n$ & Mono1 & Mix1 & Mono2 & Mix2 \\
\hline Soil type (FAO) & & Lithic Leptosol & Umbric Cambisol & Umbric Cambisol & Umbric Cambisol \\
\hline $\begin{array}{l}\text { Ah-horizon (cm) } \\
\text { B-horizon }\end{array}$ & & $\begin{array}{c}2-5 \\
>20\end{array}$ & $\begin{array}{l}5-10 \\
>20\end{array}$ & $\begin{array}{c}3-5 \\
>20\end{array}$ & $\begin{array}{l}5-10 \\
>20\end{array}$ \\
\hline $\mathbf{W R C}_{\max }(\%)$ & 40 & $63.7 \pm 3.1 \mathrm{a}$ & $65.3 \pm 1.4 \mathrm{a}$ & $65.5 \pm 2.7 \mathrm{a}$ & $73.7 \pm 4.0 \mathrm{~b}$ \\
\hline Soil moisture (\%) & 40 & $32.6 \pm 6.2 \mathrm{a}$ & $37.9 \pm 4.4 \mathrm{a}$ & $37.9 \pm 4.2 \mathrm{a}$ & $46.2 \pm 7.0 \mathrm{~b}$ \\
\hline $\mathbf{p H}(1 \mathrm{M} \mathrm{KCl})$ & 40 & $3.4 \pm 0.1 \mathrm{a}$ & $3.5 \pm 0.1 \mathrm{a}$ & $3.5 \pm 0.1 \mathrm{a}$ & $3.4 \pm 0.1 \mathrm{a}$ \\
\hline $\mathrm{C} / \mathrm{N}$ & 40 & $18.6 \pm 1.8 \mathrm{a}$ & $18.1 \pm 2.2 \mathrm{a}$ & $19.5 \pm 2.3 \mathrm{a}$ & $18.4 \pm 2.1 \mathrm{a}$ \\
\hline $\mathrm{C}_{\mathrm{org}}(\%)$ & 40 & $13.9 \pm 3.2 \mathrm{ab}$ & $11.8 \pm 2.1 b$ & $15.3 \pm 3.1 \mathrm{ac}$ & $19.1 \pm 5.0 \mathrm{c}$ \\
\hline $\mathrm{N}_{\mathrm{t}}(\mu \mathrm{g} / \mathrm{g})$ & 40 & $7.3 \pm 1.6 \mathrm{a}$ & $6.8 \pm 0.7 \mathrm{a}$ & $8.2 \pm 1.8 b$ & $11.3 \pm 3.2 \mathrm{c}$ \\
\hline $\mathrm{PO}_{4}{ }^{3-}(\mu \mathrm{g} / \mathrm{g})$ & 40 & $24.4 \pm 4.8 \mathrm{a}$ & $27.2 \pm 4.6 \mathrm{a}$ & $30.3 \pm 7.1 \mathrm{a}$ & $64.2 \pm 13.9 b$ \\
\hline $\mathrm{Ca}^{2+}(\mathrm{mg} / \mathrm{g})$ & 40 & $0.5 \pm 0.2 \mathrm{a}$ & $1.4 \pm 0.5 b$ & $1.4 \pm 0.5 b$ & $2.6 \pm 0.8 \mathrm{c}$ \\
\hline $\mathrm{Mg}^{2+}(\mu \mathrm{g} / \mathrm{g})$ & 40 & $130 \pm 45 a$ & $226 \pm 82 b$ & $194 \pm 46 b$ & $391 \pm 110 \mathrm{c}$ \\
\hline $\mathrm{K}^{+}(\mu \mathrm{g} / \mathrm{g})$ & 40 & $416 \pm 77 a$ & $456 \pm 114 a b$ & $431 \pm 62 \mathrm{ab}$ & $469 \pm 97 b$ \\
\hline $\mathrm{Al}^{3+}(\mu \mathrm{g} / \mathrm{g})$ & 40 & $606 \pm 156 a$ & $402 \pm 114 b$ & $357 \pm 132 b$ & $221 \pm 125 c$ \\
\hline $\begin{array}{l}\text { Microbial activity } \\
\left(\mu \mathrm{gCO}_{2}-\mathrm{C} / \mathrm{g} \times \mathrm{h}\right)\end{array}$ & 40 & $4.4 \pm 1.4 \mathrm{a}$ & $4.5 \pm 0.7 \mathrm{a}$ & $4.5 \pm 1.3 \mathrm{a}$ & $7.4 \pm 2.2 b$ \\
\hline Microbial biomass (mgC/g) & 40 & $4.8 \pm 0.5 \mathrm{a}$ & $3.5 \pm 1.3 b$ & $4.7 \pm 0.5 \mathrm{a}$ & $4.5 \pm 0.9 \mathrm{a}$ \\
\hline \multicolumn{6}{|l|}{ Litter mass $\left(\mathrm{g} / \mathrm{m}^{2}\right)$} \\
\hline Nov. 2001 & 8 & $393 \pm 44 b$ & $457 \pm 36 b$ & $410 \pm 19 b$ & $507 \pm 38 a$ \\
\hline Sept. 2002 & 8 & $0 \pm 0 \mathrm{~b}$ & $287 \pm 36 a$ & $92 \pm 23 b$ & $327 \pm 19 a$ \\
\hline Disappearance (\%) & & 100 & 37 & 78 & 36 \\
\hline
\end{tabular}

Differences between the plots are indicated by different letters $(p \leq 0.05$; Mann Whitney U-test).

content of the extracts $\left(\mathrm{C}_{\text {mic }}\right)$ were measured with the TOC-analyser. Specific microbial respiration $\left(q \mathrm{CO}_{2}\right)$ was calculated as microbial activity in $\mathrm{mg} \mathrm{CO}_{2}-\mathrm{C}$ per hour and $\mathrm{g} \mathrm{C}_{\text {mic }}-\mathrm{C}$. The $\mathrm{C}$-mineralisation $\left(\mathrm{C}_{\text {min }}\right)$ was calculated as microbial activity in $\mathrm{mg} \mathrm{CO}_{2}-\mathrm{C}$ per $\mathrm{g} \mathrm{C}_{\text {org }}$ and day.

\subsection{Litter sampling and extraction of Lumbricidae}

Litter was sampled at random in areas of $300 \mathrm{~cm}^{2}(n=8)$ in November 2001 after litter fall and ten months later in September 2002 before litter fall. The litter was dried, weighed, and the results multiplied by 33.3 to calculate the amount of litter in $\mathrm{g} / \mathrm{m}^{2}$.

Earthworm abundance was determined for an area of $1 / 8 \mathrm{~m}^{2}$ by hand selection from the litter and a consecutive formalin extraction [36]. Eight $1 / 8 \mathrm{~m}^{2}$ circles per site were chosen at random and sampled in May 2003. The number of individuals per $\mathrm{m}^{2}$ was calculated by summing up the number of earthworms of each single replicate per site.

\subsection{Statistical analyses}

Normal distribution of data was tested with the KolmogoroffSmirnoff-test, modified after Lillefors. Because not all data sets were normally distributed, we present the median values with the median absolute deviation and used the nonparametric Kruskal-Wallis-H-test and the Mann Whitney U-test in succession to test for differences between data sets. The limit of significance was set at $p \leq 0.05$. Two factorial analysis of variance (ANOVA) was conducted to specify the effect of species composition (oak mono/oak-hazel) and inclination (flat/steep) on soil chemical and microbial properties. Each factor appeared in a replicate number of $n=2$ and therefore the degree of freedom of the single factors was d.f. $=1$. The investigation was set up as a two factor randomised complete block design (RCBD). The soil characteristics used for analysis of variance appeared in a replicate number of 80 per factor. To avoid pseudoreplication repeated sampling never occurred at the same positions within the locations. All data were $\log (\mathrm{x}+1)$ transformed to minimize violation of normal distribution. The limit of significance was set at $p \leq 0.001$ to reduce the influence of heterogeneity of variance [39]. In the ANOVA result table the F-value, the significance-level and the $R^{2}$-value is presented. The $R^{2}$-value indicates the contribution of a specific factor to the total variance of the analysis. If a parameter's distribution is exclusively influenced by the chosen factors then the $R^{2}$-value of the model is 1.0. All statistical analyses were conducted with the computer programm SPSS 11.0. 
Table II. Two-factorial ANOVA on the effects of species composition (oak monoculture/oak-hazel) and slope gradient (steep/gentle) on selected soil properties $\left(\mathrm{C}_{\mathrm{org}}, \mathrm{N}_{\mathrm{t}}, \mathrm{PO}_{4}{ }^{3-}-\mathrm{P}, \mathrm{K}^{+}, \mathrm{Mg}^{2+}, \mathrm{Ca}^{2+}, \mathrm{Al}^{3+}, q \mathrm{CO}_{2}, \mathrm{C}_{\mathrm{min}}\right)$ at the investigation sites.

\begin{tabular}{|c|c|c|c|c|c|c|c|c|c|c|c|c|}
\hline \multirow{3}{*}{$\begin{array}{l}\text { ANOVA } \\
\text { two-way }\end{array}$} & \multicolumn{3}{|c|}{ Species composition } & \multicolumn{3}{|c|}{ Slope gradient } & \multicolumn{3}{|c|}{ Interaction } & \multicolumn{3}{|c|}{ Model } \\
\hline & \multicolumn{3}{|c|}{1} & \multicolumn{3}{|c|}{1} & \multicolumn{3}{|c|}{1} & \multicolumn{3}{|c|}{7} \\
\hline & $\mathrm{F}$ & & $R^{2}$ & $\mathrm{~F}$ & & $R^{2}$ & $\mathrm{~F}$ & & $R^{2}$ & $\mathrm{~F}$ & & $R^{2}$ \\
\hline $\mathrm{C}_{\text {org. }}$ & 0.2 & ns & & 15.3 & $* * *$ & 0.09 & 1.2 & ns & & 5.6 & $* * *$ & 0.10 \\
\hline $\mathbf{N}_{\mathrm{t}}$ & 3.8 & ns & & 54.1 & $* * *$ & 0.23 & 10.4 & ns & & 22.8 & $* * *$ & 0.31 \\
\hline $\mathrm{PO}_{4}{ }^{3-}-\mathrm{P}$ & 83.3 & $* * *$ & 0.21 & 101.6 & $* * *$ & 0.26 & 53.9 & $* * *$ & 0.14 & 80.0 & $* * *$ & 0.61 \\
\hline $\mathbf{K}^{+}$ & 4.3 & ns & & 1.3 & ns & & 0.5 & ns & & 2.0 & ns & \\
\hline $\mathrm{Mg}^{2+}$ & 37.5 & $* * *$ & 0.17 & 33.3 & $* * *$ & 0.15 & 0.3 & ns & & 23.7 & $* * *$ & 0.31 \\
\hline $\mathrm{Ca}^{2+}$ & 113.1 & $* * *$ & 0.30 & 100.8 & $* * *$ & 0.26 & 11.6 & ns & & 75.2 & $* * *$ & 0.59 \\
\hline $\mathbf{A l}^{3+}$ & 34.6 & $* * *$ & 0.14 & 53.5 & $* * *$ & 0.22 & 0.2 & ns & & 29.5 & $* * *$ & 0.36 \\
\hline$q \mathrm{CO}_{2}$ & 42.8 & $* * *$ & 0.21 & 5.6 & ns & & 0.2 & ns & & 16.2 & $* * *$ & 0.24 \\
\hline$C_{\min }$ & 19.1 & $* * *$ & 0.11 & 1.8 & ns & & 1.4 & ns & & 7.4 & $* * *$ & 0.13 \\
\hline
\end{tabular}

$* * * p \leq 0.001 ;$ ns: no significance.

\section{RESULTS}

\subsection{Organic matter}

At the mixed cultures and at the monoculture with low inclination (Mono2), acidic brown earth (Cambisol) was formed (Tab. I). At the site Mono1 the soil type was a Lithic Leptosol. There were clear differences in the thickness of the Ah-horizon between monocultures and mixed cultures (Tab. I). The thickness of the Ah-horizons was about twice as high at the mixed stands $(5-10 \mathrm{~cm})$ than at the monocultures $(2-5 \mathrm{~cm})$.

$\mathrm{WRC}_{\max }$ and soil moisture was significantly highest $(p \leq 0.05)$ at the at the mixed stand of low inclination (Mix2) but did not differ between the sites Mono1, Mix1 and Mono2 (Tab. I). The $\mathrm{C} / \mathrm{N}$ ratio ranged from 18.1 to 19.5 and did not differ significantly between the sites.

The forest floor mass after litter fall (Nov. 2001) ranged from $393-507 \mathrm{~g} / \mathrm{m}^{2}$ and did not statistically differ among the sites except for the site Mix2 which exhibited a significantly higher value (Tab. I). Ten months later, shortly before the next litter fall, the amounts of litter were substantially lower at all sites. Particularly high amounts of litter (78-100\%) disappeared from the oak monocultures. At the mixed stands the amount of litter decreased by $37 \%$ (Mix 1) and 36\% (Mix2). The amounts of litter found at Mix $1\left(287 \mathrm{~g} / \mathrm{m}^{2}\right)$ and Mix2 $\left(327 \mathrm{~g} / \mathrm{m}^{2}\right)$ were significantly higher $(p \leq 0.05)$ than those found at the monocultures (Mono1: $0 \mathrm{~g} / \mathrm{m}^{2}$; Mono2: $92 \mathrm{~g} / \mathrm{m}^{2}$ ).

The contents of $\mathrm{C}_{\text {org }}$ and $\mathrm{N}_{\mathrm{t}}$ were generally higher at the sites of low inclination than at the steep sites (Tab. I), but the difference in the content of organic carbon between the monocultures was not significant. Differences between monocultures and mixed stands did not occur except for the gentle slope which had a significantly higher nitrogen content at the mixed stand ( $p \leq 0.001)$. Accordingly, the factor "species composition" did not significantly influence $\mathrm{C}_{\text {org }}$ and $\mathrm{N}_{\mathrm{t}}$ contents in a two-way ANOVA (Tab. II). The factor "inclination" explained the variances at $9 \%\left(\mathrm{C}_{\mathrm{org}}\right)$ and $23 \%\left(\mathrm{~N}_{\mathrm{t}}\right)$.

\subsection{Soil acidity and exchangeable soil nutrients}

The soil $\mathrm{pH}$ was almost identical at all sites (3.4-3.5; Tab. I), and the contents of extractable potassium only differed marginally among the sites (416-469 $\mathrm{mg} / \mathrm{kg}$ ) (Tab. I). Only the sites Mono1 and Mix2 differed significantly from each other $(p=0.024)$. In respect to the contents of extractable calcium and magnesium there were strong differences between the sites (Tab. I). They reached the highest values at site $\operatorname{Mix} 2\left(\mathrm{Ca}^{2+}\right.$ : $\left.2.6 \pm 0.8 \mathrm{mg} / \mathrm{g} ; \mathrm{Mg}^{2+}: 391 \pm 110 \mu \mathrm{g} / \mathrm{g}\right)$ and the lowest values at site Mono1 ( $\left.\mathrm{Ca}^{2+}: 0.5 \pm 0.2 \mathrm{mg} / \mathrm{g} ; \mathrm{Mg}^{2+}: 130 \pm 45 \mu \mathrm{g} / \mathrm{g}\right)$. Differences to the other sites were highly significant $(p \leq 0.001)$; only between the sites Mix 1 and Mono2 were there no significant differences in the contents of $\mathrm{Ca}^{2+}$ and $\mathrm{Mg}^{2+}$.

The contents of $\mathrm{Al}^{3+}$ ions exhibited opposite tendencies to those found for the base cations $\mathrm{Ca}^{2+}, \mathrm{Mg}^{2+}$ and $\mathrm{K}^{+}$(Tab. I). The significantly highest value was obtained at the site Mono 1 $(606 \pm 156 \mathrm{mg} / \mathrm{kg})$, the significantly lowest value at the site Mix $2(221 \pm 125 \mathrm{mg} / \mathrm{kg})$. The $\mathrm{Al}^{3+}$ contents at the sites Mono2 $(357 \pm 132)$ and Mix $1(402 \pm 114)$ did not differ significantly from each other.

The content of extractable phosphate was more than twice as high $(p<0.001)$ at the flat mixed stand (Mix2;64.2 $\pm 13.9 \mathrm{mg} / \mathrm{kg}$ ) than at all the other sites $(24.4-30.3 \mathrm{mg} / \mathrm{kg})$ which did not differ significantly from each other (Tab. I).

Two factorial analyses of variance delivered highly significant model explanations for the contents of $\mathrm{PO}_{4}{ }^{3-}-\mathrm{P}, \mathrm{Ca}^{2+}, \mathrm{Mg}^{2+}$, and $\mathrm{Al}^{3+}$ in the soil (Tab. II). The factors "species composition" (oak-hazel/oak monoculture) and "inclination" (flat/steep) both 

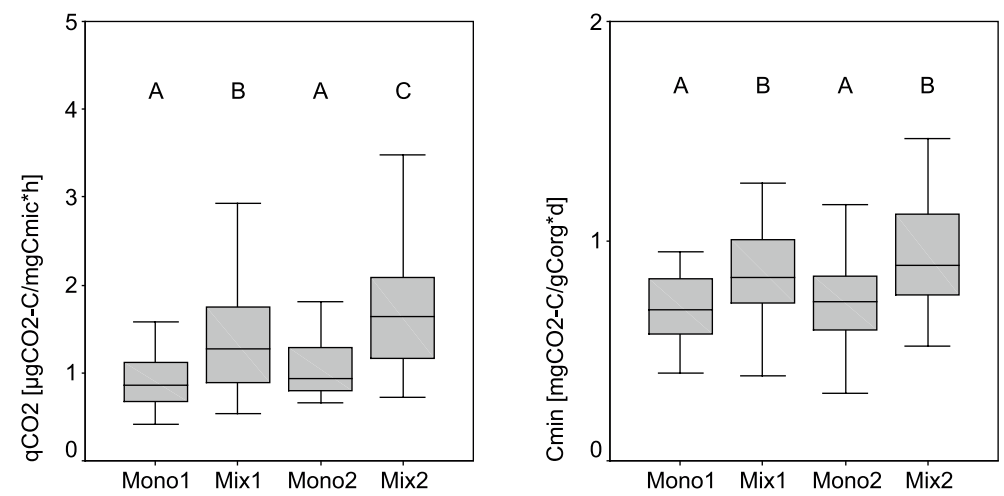

Figure 2. Specific microbial activity and carbon mineralisation $\left(\mathrm{C}_{\min }\right)$ in the topsoil of the investigation sites Mono1, Mix1, Mono2 and Mix2 (Mono $=$ oak monoculture; Mix $=$ oak-hazel; $1=25-27^{\circ}, 2=13-14^{\circ}$ ). Presented are Box-Whisker-plots. The letters above the box-plots represent the results of Mann-Whitney U-tests. Different letters indicate significant differences between the sites $(p \leq 0.05)$.

Table III. Abundance of Lumbricidae at the sites Mono1, Mix1, Mono2 and Mix2 (Mono = oak monoculture; Mix = oak-hazel; $1=25-27^{\circ}$, $\left.2=13-14^{\circ}\right)$. Presented are median values of individuals per $\mathrm{m}^{2}(n=8)$ and values in ind. $/ \mathrm{m}^{2}$.

\begin{tabular}{|c|c|c|c|c|}
\hline Sites & Mono1 & Mix1 & Mono2 & $\operatorname{Mix} 2$ \\
\hline $\begin{array}{l}\text { Individuals per } \mathrm{m}^{2} \\
\text { (median values; } n=8 \text { ) }\end{array}$ & $0 \pm 0$ & $1 \pm 1$ & $1 \pm 1$ & $2 \pm 1$ \\
\hline Individuals per $\mathrm{m}^{2}$ & $\begin{array}{c}2 \\
\text { (all juv.) }\end{array}$ & $\begin{array}{c}16 \\
\text { (all juv.) }\end{array}$ & $\begin{array}{c}21 \\
\text { (10 juv./11 ad.) }\end{array}$ & $\begin{array}{c}15 \\
\text { (7 juv./8 ad.) }\end{array}$ \\
\hline Dendrodrilus rubidus & 0 & 0 & 8 & 8 \\
\hline Lumbricus rubellus & 0 & 0 & 3 & 0 \\
\hline Dendrobaena sp. & 0 & 3 & 3 & 2 \\
\hline Lumbricus sp. & 2 & 13 & 7 & 5 \\
\hline
\end{tabular}

contributed to the model explanation for the elements $\mathrm{P}, \mathrm{Ca}, \mathrm{Mg}$ and $\mathrm{Al}$ with high $R^{2}$-values.

\subsection{Soil biota}

\subsubsection{Lumbricidae}

In total, 54 individuals were found in the litter and extracted from the soils of the investigation sites, 19 of which were adult (Tab. III). Adults were exclusively found at the flat sites: eight of them at Mix2 and eleven at Mono2. The species were Dendrodrilus rubidus and Lumbricus rubellus. Juveniles were only determined to the genus but very likely belonged to the same species. The low total number of individuals per $\mathrm{m}^{2}$ (15 at Mix2, 21 at Mono2, 16 at Mix1 and 2 at Mono1) did not permit us to compare sites statistically.

\subsubsection{Soil microbial properties}

The potential microbial activity was significantly higher at the site $\mathrm{Mix} 2\left(7.4 \mu \mathrm{gCO} \mathrm{C}_{2} \mathrm{C} / \mathrm{g} \times \mathrm{h}\right)$ compared to all the other sites (4.4-4.5 $\mathrm{mg} \mathrm{CO}_{2}-\mathrm{C} / \mathrm{g} \times \mathrm{h}$ ) which did not significantly differ from each other (Tab. I). The microbial biomass was almost identical at the sites Mono1, Mono2 and Mix2 (4.5-4.8 $\mathrm{mg} \mathrm{C}_{\text {mic }}-\mathrm{C} / \mathrm{g}$ ) but significantly lower $(p \leq 0.001)$ at site Mix1 $(3.5 \pm$ $1.3 \mathrm{mg} \mathrm{C}_{\mathrm{mic}^{-}} \mathrm{C} / \mathrm{g}$ ) (Tab. I). The specific microbial respiration $\left(q \mathrm{CO}_{2}\right)$ was significantly higher $(p \leq 0.05)$ at the oak-hazel sites than at the oak monocultures, independent of inclination (Fig. 2). While there was no significant difference between the flat and steep oak monocultures, the specific respiration was significantly higher at the flat hazel site (Mix2) than at the steep hazel site (Mix1).

The carbon mineralisation was generally higher at the mixed stands than at the oak monocultures $(p \leq 0.05)$ (Fig. 2). The highest value was obtained for the mixed stand at low slope gradient $\left(0.89 \pm 0.21 \mathrm{mgCO}_{2}-\mathrm{C}_{\mathrm{gC}}\right.$ org $\left.\times \mathrm{d}\right)$ and the lowest value for the steep monoculture $\left(0.69 \pm 0.11 \mathrm{mgCO}_{2}-\mathrm{C} / \mathrm{gC}_{\text {org }} \times \mathrm{d}\right)$. There were no statistical differences between steep and gentle slopes when comparing sites of the same plant composition (monoculture/mixed stand).

Two factorial analysis of variance revealed a highly significant $(p<0.001)$ influence of the factor "species composition" (oak mono/oak-hazel) on the specific microbial respiration and the carbon mineralisation in the soil (Tab. II). Inclination did not affect microbial properties. 


\section{DISCUSSION}

\subsection{Organic matter}

Soils of many simple oak coppice forests in the investigation area are extensively degraded by erosion. Usually, soil erosion is mostly affected by water and wind [27] and removes the finest and most fertile soil particles [9]. In our investigation area a high population density of red deer (20 ind./100 ha) enhances soil erosion processes through grazing and trampling. As a result we observed a significant reduction in the organic matter content and the activity of the soil biota in such degraded soils in a previous study [28]. The impact of red deer was pronounced at windward sites and high slope gradients $\left(>25^{\circ}\right)$.

In the present study soil organic carbon and total nitrogen contents were mostly higher $(p \leq 0.01)$ in the stands of low slope gradient than in the stands at the steep slope (Tab. I), a fact which points to increased erosion and run-off of soluble $\mathrm{C}$ - and $\mathrm{N}$-compounds at high slope gradients [21, 22].

We assumed that hazel reduces the wind velocity close to the soil surface at windward forest sites. This would prevent the drift of litter and fertile soil from the ground and therefore reduce organic matter loss and nutrient depletion. As oak leaves decompose slowly due to the high concentration of phenolic compounds the huge reduction $(78-100 \%)$ in forest floor mass between November 2001 and September 2002 in oak-monocultures was mainly evoked by wind drift and downhill transport. On forest paths, in troughs or at foot slopes we generally found thick layers of oak litter accumulating from downhill transport. In the mixed stands litter remained on the ground and its decomposition contributed to the formation of thicker Ahlayers compared to the monocultures (Tab. I). However, the higher aboveground organic matter mass (O-horizon) in mixed stands compared to monocultures was not reflected by differences in the contents of organic carbon and total nitrogen and the $\mathrm{C} / \mathrm{N}$ ratio in the mineral soil (A-layer) (Tab. I).

\subsection{Soil acidity and exchangeable soil nutrients}

Litterfall is a major component of nutrient cycles in forest ecosystems [35]. Hazel leaves as well as leaves of other phaenerophytes like lime (Tilia chordata) and cherry (Prunus avium) are rich in base cations $\left(\mathrm{Ca}^{2+}, \mathrm{Mg}^{2+}, \mathrm{K}^{+}\right)$[16]. It is known that the addition of alkaline plant material to acidic soils can appreciably increase the soil $\mathrm{pH}$ and the content of exchangeable soil nutrient status $[14,30,45]$. In our study, contents of exchangeable $\mathrm{Ca}^{2+}$ and $\mathrm{Mg}^{2+}$ were significantly higher $(p \leq 0.001)$ in soils under mixed stands than in monocultures (Tab. I). However, the soil $\mathrm{pH}$ was not affected when hazel litter contributed to litter decomposition (Tab. I). In contrast, the content of $\mathrm{Al}^{3+}$ was significantly lower $(p \leq 0.001)$ in soils of the mixed stands (Tab. I). Soil conditions beneath hazel seem to have favored the complexation of $\mathrm{Al}^{3+}$ ions to organic compounds in the Ahhorizon as already described in previous studies $[15,18] . \mathrm{Al}^{3+}$ ions are also known to complex with phosphate ions in the soil and thus to prevent P-uptake by plant roots $[6,8]$. Consequently, we assume that the higher content of plant-available phosphate beneath hazel (Tab. I) resulted from a lower $\mathrm{Al}^{3+}$ content in soils of mixed stands compared to soils from mono- cultures. Potassium contents did not differ between the sites (Tab. I), possibly due to the high mobility of $\mathrm{K}^{+}$ions in soils [37].

\subsection{Soil biota}

Decomposers are known to be influenced by nutrient availability, substrate quality and microclimatic conditions $[1,26$, $34]$. Hazel litter is highly degradable because of the lower concentrations of polyphenolic substances in comparison to oak and beech leaves [33, 40]. Many studies suggest that the chemical composition and the species composition of the leaf litter influence its decomposition $[20,44,50]$ and that these factors prevail over others controlling litter decomposition under favourable climatic conditions [11]. We therefore hypothesized that lumbricids and microorganisms would be favoured in mixed oak-hazel stands compared to oak monocultures.

Microbial respiration is supposed to be higher in tree leaf litter mixtures than in single-species litters [25]. Such a relationship was found for the low inclination site but differences at the steep site were marginal (Tab. I). The microbial biomass was even lower in soils of mixed stands than in the monocultures which conflicts with relationships found in earlier studies $[7,20,34]$. The specific microbial respiration $\left(q \mathrm{CO}_{2}\right)$ evaluates the efficiency of soil microbial populations in utilizing organic $\mathrm{C}$-compounds [13]. Increases in $q \mathrm{CO}_{2}$ are often interpreted as a result of unfavourable conditions ("stress") for the microbiota $[3,4]$. In contrast to the potential microbial activity we generally found increased values for the specific microbial respiration in our mixed stands (Fig. 2). "Stress" can be excluded as a reason for higher $q \mathrm{CO}_{2}$-values because $\mathrm{pH}$, soil texture, humidity and carbon and nitrogen availability were similar or even higher in soils of the mixed stands than in monocultures. Here, the $q \mathrm{CO}_{2}$ could have been influenced by density-dependant interactions, nutrient availability and top-down effects [5, $29,46]$. For example, selective arthropod grazing may reduce the microbial biomass without reducing the microbial activity [19, 20, 51]. Significantly higher carbon mineralisation (Fig. 2) at the mixed stands of this study also point to a stress-independent effect and suggest that conditions for decomposition processes are better in mixed stands than in oak monocultures.

Compared to other studies $[12,48]$, the abundance and diversity of Lumbricidae found here was very low (Tab. III), too low to compare sites statistically. This may be due to the low soil $\mathrm{pH}$ at all sites, which is known to reduce hatching success, enhance weight loss of aging adults and to hamper juvenile growth of lumbricids $[8,23,38]$. The absence of mature individuals at the steep sites and the virtually absence of individuals at the steep oak monoculture (Tab. III) suggest that the conditions at the steep sites might be even less favourable for lumbricids.

\section{CONCLUSION}

Hazel positively affects nutrient cycling in degraded oak forests. It reduces the wind velocity on the ground and traps litter to allow for accumulation of organic matter. Moreover, decomposition of hazel or oak/hazel-litter mixtures increases the content of plant-available calcium, magnesium and phosphate and supports the complexation of toxic aluminium ions. 
Consequently, sustainable forest management in oak forests should include the growth of hazel and further base-rich shrubs and trees.

Acknowledgements: We highly appreciate the support from the Forestry Office Adenau (Rheinland-Pfalz), particularly Martin Kaiser and Markus Noack. We are also grateful to Fred Bartlett and Marie-Louise Schmidt for language comments.

\section{REFERENCES}

[1] Aerts R., Climate, leaf litter chemistry and leaf litter decomposition in terrestrial ecosystem: a triangular relationship, Oikos 79 (1997) 439-449.

[2] Alef K., Methodenhandbuch Bodenmikrobiologie, Ecomed, Landsberg/Lech, 1991.

[3] Anderson T.-H., Domsch K.-H., Application of eco-physiological quotients $(q \mathrm{CO} 2$ and $q \mathrm{D})$ on microbial biomasses from soils of different cropping histories, Soil Biol. Biochem. 22 (1990) 251-255.

[4] Anderson T.-H., Domsch K.-H., The metabolic quotient for $\mathrm{CO}_{2}$ $\left(q \mathrm{CO}_{2}\right)$ as a specific activity parameter to assess the effect of environmental conditions, such as $\mathrm{pH}$, on the microbial biomass of forest soils, Soil Biol. Biochem. 25 (1993) 393-395.

[5] Anderson J.-M., Ineson P., Interactions between microorganisms and soil invertebrates in nutrient flux pathways of forest ecosystems, in: Anderson J.-M., Rayner A.D.M., Walter D.W.H. (Eds.), Invertebrate-microbial interactions, University Press, Cambridge, 1984, pp. 59-88.

[6] Andersson M., Toxicity and tolerance of aluminium in vascular plants. A literature review, Water Air Soil Pollut. 39 (1988) 335379.

[7] Bauhus J., Paré D., Côté L., Effects of tree species, stand age and soil type on soil microbial biomass and its activity in a southern boreal forest, Soil Biol. Biochem. 30 (1998) 1077-1089.

[8] Bengtsson G., Gunnarsson T., Rundgren S., Effects of metal pollution on the earthworm Dendrobaena rubida (Sav.) in acidified soils, Water Air Soil Pollut. 28 (1986) 361-383.

[9] Caravaca F., Lax A., Albaladejo J., Organic matter, nutrient contents and cation exchange capacity in fine fractions from semiarid calcareous soils, Geoderma (1999) 161-176.

[10] Carlisle A., Brown A.H.F., White E.J., Litter fall, leaf production and the effects of defoliation by Tortrix viridana in a sessile oak (Quercus petraea) woodland, J. Ecol. 54 (1966) 65-85.

[11] Coûteaux M.-M., Bottner P., Berg B., Litter decomposition, climate and litter quality, Tree 10 (1995) 63-66.

[12] David J.-F., Ponge J.-F., Aroin P., Vannier G., Reactions of the macrofauna of a forest mull to experimental perturbations of litter supply, Oikos 61 (1991) 316-326.

[13] Dilly O., Munch J.-C., Ratios between estimates of microbial biomass content and microbial activity in soils, Biol. Fertil. Soils 27 (1998) 374-379.

[14] Finzi A.C., Canham C.D., Van Breemen N., Canopy tree-soil interactions within temperate forests: species effects on $\mathrm{pH}$ and cations, Ecol. Appl. 8 (1998) 447-454.

[15] Gerke J., Aluminium complexation by humic substances and aluminium species in the soil solution, Geoderma 63 (1994) 165-175.

[16] Heinze M., Fiedler H.J., Ernährung der Gehölze, in: Lyr H., Fiedler H.J., Tranquillini W. (Eds.), Physiologie und Ökologie der Gehölze, Fischer, Jena, 1992, pp. 43-115.

[17] Hornburg V., Welp G., Brümmer G.W., Verhalten von Schwermetallen in Böden. 2. Extraktion mobiler Schwermetalle mittels $\mathrm{CaCl}_{2}$ und $\mathrm{NH}_{4} \mathrm{NO}_{3}$, Z. Pflanzenernähr. Bodenkd. 158 (1995) 137-145.
[18] Hue N.V., Craddock G.R., Adams F., Effect of organic acids on aluminium toxicity in subsoils, Soil Sci. Soc. Am. J. 50 (1994) 28-34.

[19] Kandeler E., Winter B., Kampichler C., Bruckner A., Effects of mesofaunal exclusion on microbial biomass and enzymatic activities in field mesocosms, in: Ritz K., Dighton J., Giller K.E. (Eds.), Beyond the biomass - Compositional and functional analysis of soil microbial communities, John Wiley and Sons, Chichester, 1994, pp. 181-189.

[20] Kautz G., Topp W., Nachhaltige waldbauliche Maßnahmen zur Verbesserung der Bodenqualität, Forstwiss. Centralbl. 117 (1998) $23-43$.

[21] Lal R., Losses of plant nutrients in runoff and eroded soil, in: Rosswall T. (Ed.), Nitrogen cycling in West African Ecosystems, 1980, pp. 31-38.

[22] Lal R., Global soil erosion by water and carbon dynamics, in: Lal R., Kimble J., Levine E., Stewart B.A. (Eds.), Soil management and greenhouse effect, CRC/Lewis, Boca Raton, 1995, pp. 131-142.

[23] Laverack M.S., Tactile and chemical perceptions in earthworms II Responses to acid pH solutions, Comp. Biochem. Physiol. 2 (1961) 22-34.

[24] Marschner B., Noble A.D., Chemical and biological processes leading to the neutralisation of acidity in soil incubated with litter material, Soil Biol. Biochem. 32 (2000) 805-813.

[25] McTiernan K.B., Ineson P., Coward P.A., Respiration and nutrient release from tree leaf litter mixtures, Oikos 78 (1997) 527-538.

[26] Melillo J.M., Aber J.D., Muratore J.F., Nitrogen and lignin control hardwood leaf litter decomposition dynamics, Ecology 63 (1982) 621-626.

[27] Mitchell P.D., Lakshminarayan P.G., Otake T., Babcock B.A., The impact of soil conservation policies on carbon sequestration in agricultural soils of the Central United States, in: Lal R., Kimble J., Follett R.F., Stewart B.A. (Eds.), Management of carbon sequestration in soil, CRC Press, Boca Raton, pp. 125-142.

[28] Mohr D., Topp W., Forest soil degradation in slopes of the low mountain range of Central Europe - Do deer matter? Forstwiss. Centralbl.120 (2001) 220-230.

[29] Mohr D., Nicolini F., Topp W., Sind mikrobielle Parameter verlässliche Indikatoren für Bodenqualität? Eine Synthese aus Freilanduntersuchungen und Laborversuchen, Mitt. Dtsch. Bodenkd. Ges. 99 (2002) 163-164.

[30] Neirynck J., Mirtcheva S., Sioen G., Lust N., Impact of Tilia platyphyllos Scop., Fraxinus excelsior L., Acer pseudoplatanus L., Quercus robur L. and Fagus sylvatica L. on earthworm biomass and physico-chemical properties of loamy topsoil, For. Ecol. Manage. 133 (2000) 275-286.

[31] Noble A.D., Randall P.J., The impact of trees and fodder shrubs on soil acidification, Rural Industries Research and Development Corporation, Canberra, 1998.

[32] Noble A.D., Zenneck I., Randall P.J., Leaf litter ash alkalinity and neutralisation of soil acidity, Plant Soil 179 (1996) 293-302.

[33] Perel T.S., Sokolov D.F., A quantitative assessment of the role of earthworms Lumbricus terrestris L. (Lumbricidae, Oligochaeta) in processing forest litter, Zool. Zh. (1964) 1618-1624.

[34] Priha O., Grayston S.J., Hiukka R., Pennanen T., Smolander A., Microbial community structure and characteristics of the organic matter in soils under Pinus sylvestris, Picea abies and Betula pendula at two forest sites, Biol. Fertil. Soils 33 (2001) 17-24.

[35] Ranger J., Gerard F., Lindemann F., Gelhaye D., Gelhaye L., Dynamics of litterfall in a chronosequence of Douglas fir (Pseudotsuga menziesii Franco) stands in the Beaujolais mounts (France), Ann. For. Sci. 60 (2003) 475-488.

[36] Raw F., Estimating earthworm populations by using formalin, Nature 184 (1959) 1961

[37] Remezov N.P., Pogrebniak P.S., Forest soil science, Israel Program for Scientific Translation, Jerusalem, 1969. 
[38] Rundgren S., Nilsson P., Sublethal effects of aluminium in acid soils: The usefulness of Dendrodrilus rubidus (Sav.) in a laboratory test system, Pedobiologia 41 (1997) 417-436.

[39] Sachs L., Angewandte Statistik, 7 Aufl., Springer, Berlin, 1992.

[40] Satchell J.E., Lowe D.G., Selection of leaf litter by Lumbricus terrestris, in: Graff O., Satchell J.E. (Eds.), Progress in soil biology, North Holland Publ. Co., Amsterdam, 1967, pp. 102-119.

[41] Schlichting E., Blume H.P., Bodenkundliches Praktikum, Paul Parey, Hamburg, 1966.

[42] Skambracks D., Zimmer M., Combined methods for the determination of microbial activity of leaf litter, Eur. J. Soil Biol. 34 (1998) $105-110$.

[43] Steubing L., Fangmeyer A., Pflanzenökologisches Praktikum, Ulmer, Stuttgart, 1992.

[44] Swift M.J., Heal O.W., Anderson J.M., Decomposition in terrestrial ecosystems, Blackwell, Oxford, 1979.

[45] Tang C., Sparling G.P., McLay C.D.A., Raphael C., Effect of shortterm legume residue decomposition on soil acidity, Aust. J. Soil Res. 37 (1999) 561-573.
[46] Tiunov A.V., Scheu S., Microbial respiration, biomass, biovolume and nutrient status in burrow walls of Lumbricus terrestris L. (Lumbricidae), Soil Biol. Biochem. 31 (1999) 2039-2048.

[47] Vance E.D., Brookes P.C., Jenkinson D.S., An extraction method for measuring soil microbial C, Soil Biol. Biochem. 1 (1987) 703-707.

[48] Zajonc I., Synusia analysis of earthworms (Lumbricidae, Oligochaeta) in the oak-hornbeam forest in south-west Slovakia, in: Duvigneaud P. (Ed.), Productivity of forest ecosystems, UNESCO, Paris, pp. 443-452.

[49] Zeien H., Brümmer G.W., Chemische Extraktion zur Bestimmung von Schwermetallbindungsformen in Böden, Mitt. Dtsch. Bodenkd. Ges. 59 (1989) 505-510.

[50] Zimmer M., Is decomposition of woodland leaf litter influenced by its species richness? Soil Biol. Biochem. 34 (2002) 277-284.

[51] Zimmer M., Topp W., Relationships between woodlice (Isopoda: Oniscoidea) and microbial density and activity in the field, Biol. Fertil. Soils 30 (1999) 117-123. 